4) С экономической точки зрения внедрение инновационных технологий на экономическое предприятие, способствует развитию рыночной экономики, увеличении «ВВП» т.е. поднятию предприятий на новый уровень. В случае с санкциями, использование нововведений плодотворно сказалось на отечественном рынке.

1. Атласова М.И. Влияние инноваций на качество работы и конкурентоспособность предприятия// Приволжский научный вестник.-2017.-№5.-С-4

2. Агафонов Г. В, Кульнева Н. Г. Сборник научных статей и докладов III Международной научнопрактической конференции (г. Воронеж, 26-27 октября 2017 года) «ИННОВАЦИОННЫЕ РЕШЕНИЯ ПРИ ПРОИЗВОДСТВЕ ПРОДУКТОВ ПИТАНИЯ ИЗ РАСТИТЕЛЬНОГО СЫРЬЯ». - Воронеж.- 2017

3. ПИЩЕВЫЕ ДОБАВКИ В ПРОДУКТАХ ПИТАНИЯ. .[ Электронный pecypc] URL: https://ru.siberianhealth.com/ru/blogs/pitanie/pishchevye-dobavki-v-produktakh-pitaniya/ (дата обращения: 08.04.2021)

\title{
Махова А.В., Журавель Т.С. \\ Анализ уровня оплаты труда наемных работников по субъектам Российской Федерации за 2015-2019 гг.
}

\author{
ФГБОУ ВО «КубГУ» \\ (Россия, Славянск-на-Кубани)
}

doi: 10.18411/trnio-11-2021-104

\section{Аннотация}

Материалы данной статьи включают в себя анализ уровня среднемесячной заработной платы наемных работников в организациях, у индивидуальных предпринимателей и физических лиц по Российской Федерации, Центральному, Северо-Западному, Южному, Северо-Кавказскому, Приволжскому, Уральскому, Сибирскому, Дальневосточному федеральным округам и Краснодарскому краю в период с 2015 по 2019 гг.

Ключевые слова: региональная экономика, заработная плата, уровень заработной платы, наемные работники, индивидуальные предприниматели.

\section{Abstract}

The Materials of this article include an analysis of the level of average monthly wages of employees in organizations, among individual entrepreneurs and individuals in the Russian Federation, Central, North-West, South, North Caucasus, Volga, Ural, Siberian, Far Eastern Federal Districts and Krasnodar region in the period from 2015 to 2019.

Keywords: regional economy, wages, salary level, employees, individual entrepreneurs.

\section{Введение}

Основным источником доходов людей, в возрасте от 18 до 65 лет, является заработная плата, то есть вознаграждение за труд, которое напрямую зависит от квалификации работника, степени сложности труда, его условий, социальной значимости. Однако есть еще один немало важный фактор, определяющий уровень оплаты труда. Это местоположение организации, предприятия. Ведь каждый регион в Российской Федерации уникален, он отличается своими климатическими особенностями, производимыми товарами и услугами, уровнем развития экономики и промышленности. Именно экономика является определяющим звеном в определении среднемесячной заработной платы по субъектам РФ. Ниже рассмотрены суммы оплаты труда и причины их различия по каждому региону Российской Федерации, а также подробнее разобрана данная ситуация в Краснодарском крае в период с 2015 по 2019 гг. 


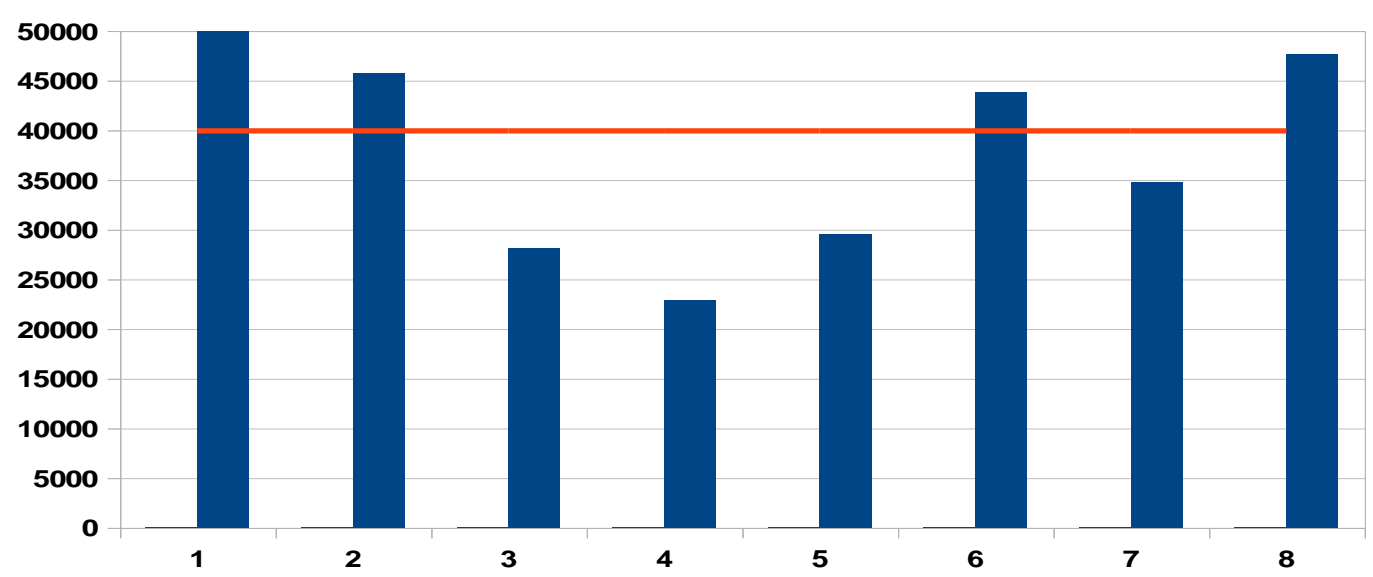

Рисунок 1. Среднемесячная начисленная заработная плата наёмных работников в организациях, $y$ индивидуальных предпринимателей и физических лии по округам РФ

за 2019 г. относительно среднегодовой заработной платы в $Р \Phi^{*}(* 1$. Центральный федеральный округ, 2.

Северо-Западный федеральный округ, 3. Южный федеральный округ, 4. Северо-Кавказский федеральный округ,

5. Приволюский федеральный округ, 6. Уральский федеральный округ, 7. Сибирский федеральный округ, 8.

Дальневосточный федеральный округ)

Анализируя среднемесячную заработную плату наемных работников в организациях, у индивидуальных предпринимателей и физических лиц по округам РФ за 2019 г. (рисунок 1), видно, что наибольшую среднемесячную оплату труда получили работники в Центральном федеральном округе, где она составляет 50166 руб., наименьшая сумма заработной платы наемных работников наблюдается в Северо-Кавказском федеральном округе, и составляет 22920 руб. Высокий уровень оплаты труда в Центральном федеральном округе объясняется тем, что в состав округа входят крупные многомиллионные города, в которых производственный процесс хорошо развит. Низкий уровень оплаты труда в Северо-Кавказском федеральном округе связан с тем, что в регионе практически отсутствует промышленный сектор экономики. В соотношении среднемесячной заработной платы в федеральных округах с заработной платой по Российской Федерации видно, что из 8 округов только 4 превышают средний уровень по России. Это Центральный, Северо-Западный, Уральский и Дальневосточный федеральные округа. Причиной такой разницы является высокий уровень развития промышленности, влекущий за собой конкуренцию как среди работников, так и среди работодателей, опасное производство, дороговизна жизни. Уровень заработной платы в остальных округах оказался намного ниже средней зарплаты по стране. Это связано, прежде всего, с тем, что большая часть населения проживает в малых городах, сельских населенных пунктов, где отсутствуют крупные предприятия, вследствие чего никакой экономики, промышленности и конкуренции не существует.

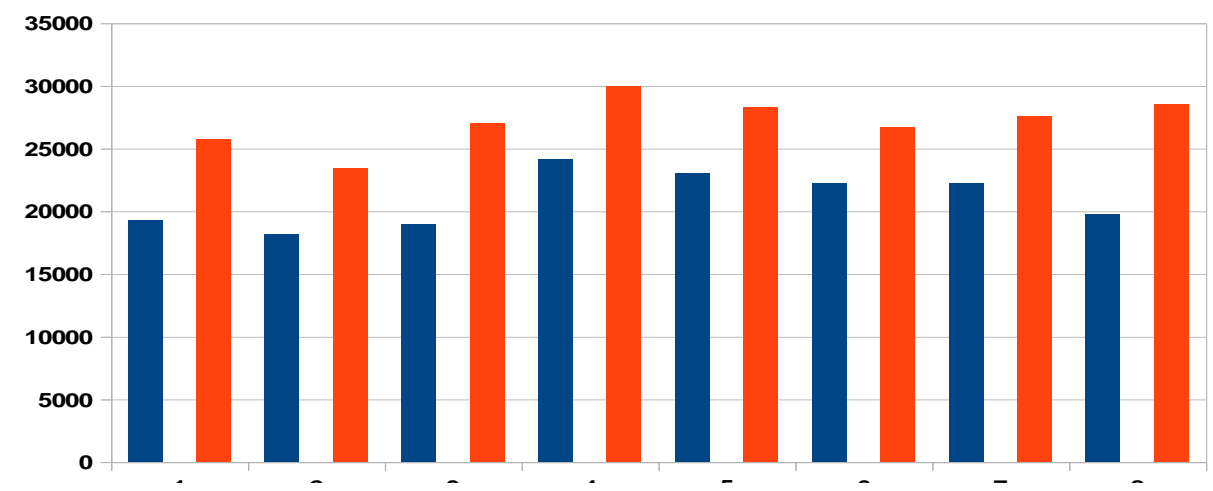

Рисунок 2. Среднемесячная начисленная заработная плата наёмных работников в организаџиях, $y$ индивидуальных предпринимателей и физических лии в субъектах Южного федерального округа за 2015 и 2019 г2. * (* 1. Республика Адыгея, 2. Республика Калмыкия, 3. Республика Крылм, 4. Краснодарский край, 5. Астраханская область, 6. Волгоградская область, 7. Ростовская область, 8. г. Севастополь) 
При анализе данных о среднемесячной заработной платы наемных работников в организациях, у индивидуальных предпринимателей и физических лиц в субъектах Южного федерального округа за 2015 и 2019 гг. (рисунок 2) заметно, что за 4 года во всех субъектах ЮФО уровень зарплаты увеличился. Наибольший рост оплаты труда наблюдается в г. Севастополь, и он составил 8727 руб. (с 19754 руб. в 2015 г. до 28481 руб. в 2019 г.), наименьший рост - в Волгоградской области, где уровень заработной платы составил 4468 руб. (с 22241 руб. в 2015 г. до 26709 руб. в 2019 г.). Причиной столь большого роста заработной платы в г. Севастополь стало то, что после присоединения Крыма к России в 2014 г. на полуострове были построены различные предприятия, ведутся строительные работы, появилась конкуренция в промышленной сфере, от чего работники получают достойную плату за свой труд. Обратная ситуация наблюдается в Волгоградской области, где крупные промышленные предприятия не развиваются, оборудование устаревает и качество работы, соответственно, снижается. Отсюда и малый рост среднемесячной заработной платы работников.

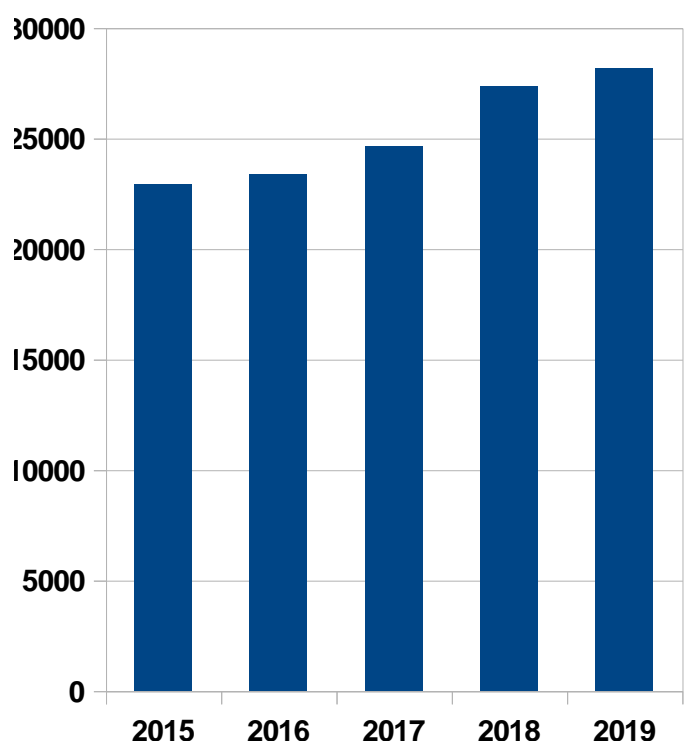

Рисунок 3. Среднемесячная начисленная заработная плата наёмных работников в организаииях, у индивидуальных предпринимателей и физических лии в Южном федеральном округе за 2015-2019 22.

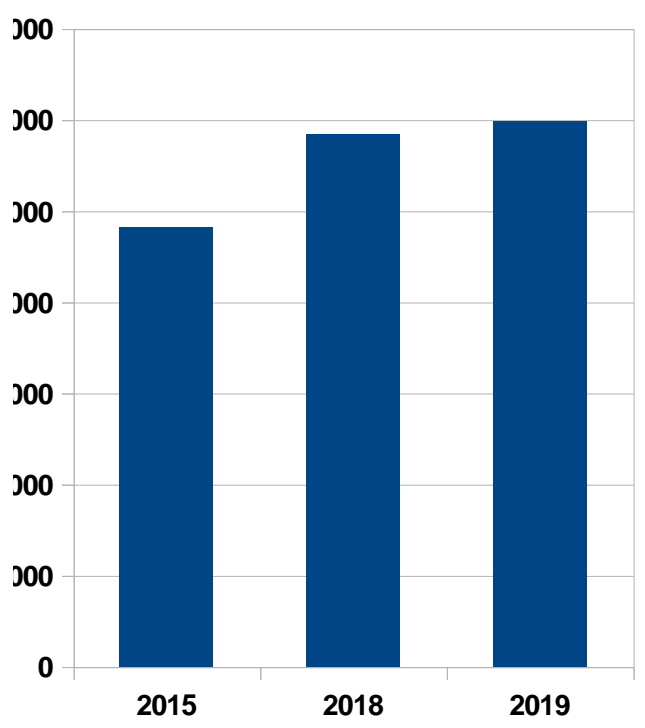

Рисунок 4. Среднемесячная начисленная заработная плата наёмных работников в организациях, у индивидуальных предпринимателей и физических лии по Краснодарскому краю за 2015, 2018 и 2019 г2.

Исследуя данные о среднемесячной начисленной заработной плате наемных работников в организациях, у индивидуальных предпринимателей и физических лиц в Южном федеральном округе за 2015-2019 гг. (рисунок 3), можно сделать вывод, что уровень оплаты труда непрерывно растет с 22896 руб. в 2015 г. до 28167 руб. в 2019 г. Наибольший рост наблюдается в период с 2017 по 2018 гг. и составил 2727 руб., наименьший рост (в промежутке между 2015 и 2016 гг.) - 455 руб. Причина большого прироста заработной платы заключается в том, что в связи с открытием Крымского моста увеличилось количество отдыхающих, а значит и появились новые туристические поездки, торговые точки, повышение числа рабочих мест и их оплаты труда. Однако до этого в период с 2015 по 2016 гг. виден малый прирост из-за введенных против России санкций и последующих за ними финансового кризиса, обесценивания рубля, инфляции цен.

При анализе данных о среднемесячной начисленной заработной плате наемных работников в организациях, у индивидуальных предпринимателей и физических лиц по 
Краснодарскому краю за 2015, 2018 и 2019 гг. (рисунок 4) наблюдается рост оплаты труда с 24115 руб. в 2015 г. до 29922 руб. в 2019 г. Наибольший рост уровня заработной платы происходит в период 2015 по 2018 гг. и составил 5084 руб., наименьший прирост ( в промежутке с 2018 по 2019 гг.) - 723 руб. Повышение уровня оплаты труда в 2015 - 2018 гг. обусловлено тем, что благодаря введенным в 2014 г. санкциям против России, в Краснодарском крае началась политика расширения и поддержания агропромышленного комплекса, транспортировка продукции в сторону центральной и северной России. Однако уже в период с 2018 по 2019 гг. повышение уровня заработной платы значительно ниже, так как рубль стал терять свою ценность на мировом рынке, высокий уровень инфляции по сравнению с предыдущим годом.

\section{Заключение}

На сегодняшний день виден различный уровень оплаты труда работникам во всех субъектах РФ, причем не все достигают отметки «среднемесячная заработная плата по России». Так, наименьший разрыв между средней зарплатой по стране и в регионе за 2019 г. замечаем в Сибирском федеральном округе, он составил 5112 руб. Наибольший разрыв был в Северо-Кавказском федеральном округе - 17001 руб. Эти данные можно объяснить тем, что в округах мало крупных промышленных предприятий. Сибирский федеральный округ не на много меньше общероссийской оплаты труда, т. к. здесь сосредоточены крупнейшие запасы природных ресурсов, освоение и добыча которых дорожает из-за сурового климата. При сравнении уровня заработной платы в Южного федерального округа за 2015 и 2019 гг. виден рост в каждом крупном городе региона. Наибольший рост наблюдается в г. Севастополь и составил 8727 руб., наименьший рост - в Волгоградской области.

Исходя из анализа данного показателя, можно говорить, что экономика в стране за исследуемый период улучшилась, расширяется промышленный сектор, тем самым улучшая уровень заработной платы граждан.

$$
\text { *** }
$$

1. Официальный сайт Федеральная служба государственной статистики [Электронный ресурс] - URL: https://rosstat.gov.ru/statistic

2. Рынок труда, занятость и заработная плата // Федеральная служба государственной статистики: сайт. - 2021. - URL: -https://rosstat.gov.ru/labor_market_employment_salaries (дата обращения: 15.09.2021).

3. Иткинд А. Н. Оплата труда наемных работников: теоретические основы, мировой опыт и Российская практика [Электронный ресурс] - URL: - https://cyberleninka.ru/article/n/oplata-truda-naemnyh-rabotnikovteoreticheskie-osnovy-mirovoy-opyt-i-rossiyskaya-praktika

4. Журавель Т. С., Махова А. В. Анализ позитивной составляющей индикатора достойного труда в России за 2001-2018 гг. [Текст] - Международный научно-исследовательский журнал "Человек и современный мир" №5 (42) 2020 г. -8 c.

\section{Микляева Ю.В., Зверева С.А., Хорина И.В. Основные факторы инновационного развития региона}

Самарский государственный технический университет (Россия, Самара)

doi: 10.18411/trnio-11-2021-105

\section{Аннотация}

В обеспечении устойчивого, динамичного, сбалансированного социальноэкономического развития страны первостепенное значение имеют процессы инновационного развития экономики регионов. В современных условиях проблемы определения состава факторов, оказывающих влияние на инновационное развитие региона, методологии измерения этого влияния и создания инструментария его оценки являются актуальными в условиях поиска возможных механизмов стимулирования региональной инновационной активности.

Ключевые слова: инновации, региональная экономика, инновационное развитие региона, человеческий капитал, кадровые ресурсы, экономический рост, инновационная деятельность. 